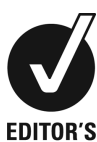

CHOICE

\title{
An unusual treatable cause for proximal muscle weakness
}

\author{
Sahana Shetty, ${ }^{1}$ Nitin Kapoor, ${ }^{1}$ Vinoo Mathew Cherian, ${ }^{2}$ Thomas Vizhalil Paul $^{1}$
}

${ }^{1}$ Christian Medical College, Vellore, Tamil Nadu, India ${ }^{2}$ Department of Orthopedics, Christian Medical College, Vellore, Tamil Nadu, India

\section{Correspondence to}

Professor Thomas Vizhalil Paul, thomasvpaul@yahoo.com

Accepted 18 December 2014

\section{DESCRIPTION}

A 37-year-old man presented with generalised bony pains and severe progressive lower limb proximal weakness of 2 years duration. There was no preceding history of fever, morning stiffness, muscle pain, joint swellings, fractures, skin rashes, photosensitivity, diarrhoeal illness or taking long-term medications for any systemic conditions. There was no significant family history. Examination was unremarkable except for severe lower limb proximal muscle weakness and bony tenderness.

His biochemical evaluation was as followsserum phosphorus: $1.2 \mathrm{mg} / \mathrm{dL}(\mathrm{N}: 2.5-4)$, corrected serum calcium: $8.8 \mathrm{mg} / \mathrm{dL}$ (N: 8.2-10.3), serum alkaline phosphatase: $380 \mathrm{U} / \mathrm{L}(\mathrm{N}: 40-125)$, serum creatinine: $1.1 \mathrm{mg} / \mathrm{dL}(\mathrm{N}: 0.6-1.2)$, intact parathyroid hormone: $52 \mathrm{pg} / \mathrm{mL}$ ( $\mathrm{N}: 8.0-50)$, 25-hydroxy vitamin $\mathrm{D}: 46 \mathrm{ng} / \mathrm{mL}$ (N: $30-70 \mathrm{ng} / \mathrm{mL}$ ), venous bicarbonate:

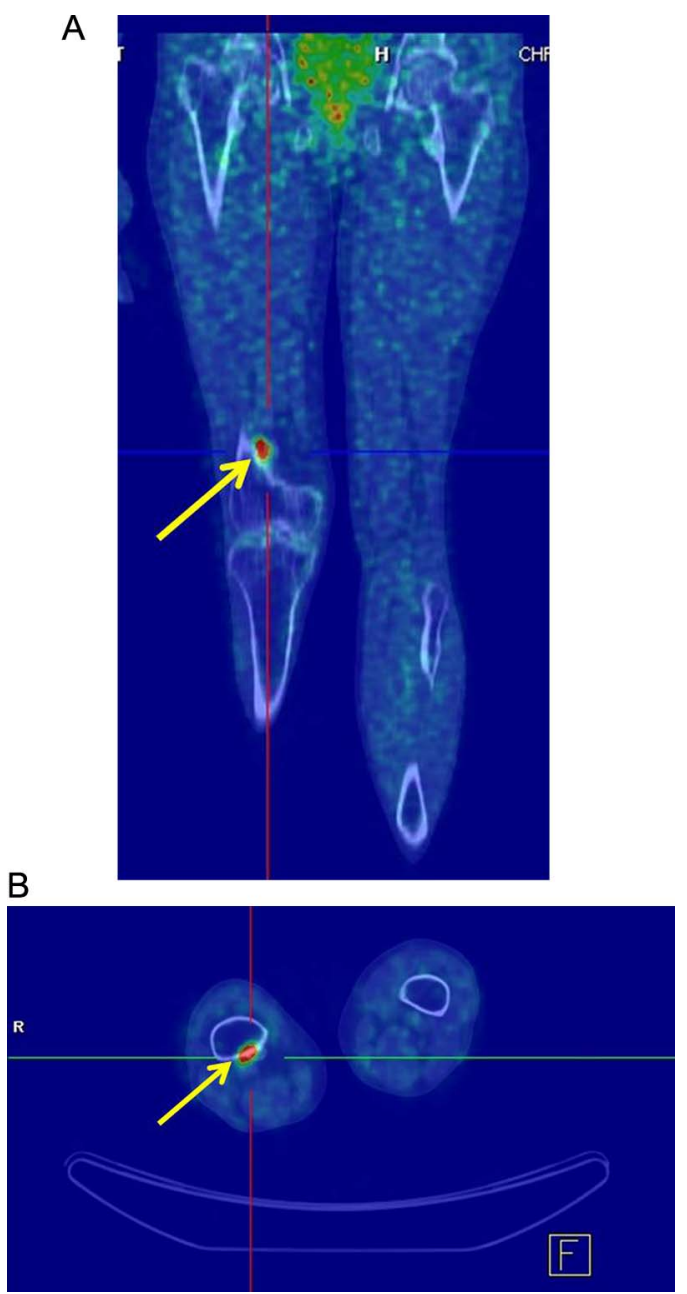

Cherian VM, et al. BMJ Case Rep Published online: [please include Day Month Year] doi:10.1136/bcr-2014208731

CrossMark
Figure 1 ( $A$ and $B)$ : positron emission tomographyGA 68 DOTA scintigraphy showing a lesion with increased tracer uptake in the right distal femur.

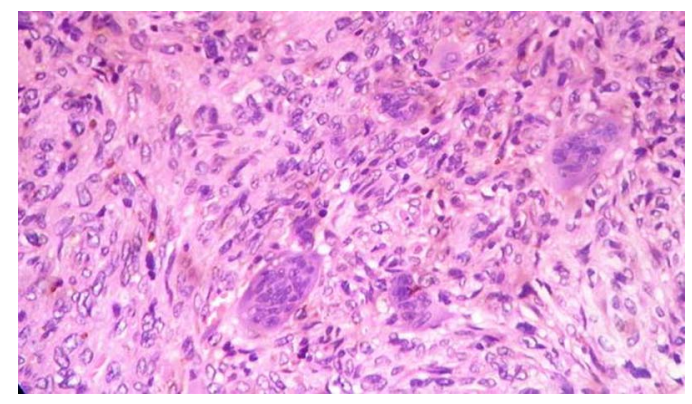

Figure 2 Histopathology of the excised mesenchymal tumour showing aggregates of osteoclast-like giant cells.

$25 \mathrm{mmol} / \mathrm{L}$ (N: 21-28), tubular maximum for phosphate (TmP/glomerular filtration rate): $1.3 \mathrm{mg} / \mathrm{dL}$ (N: 2.5-4). Fibroblast growth factor (FGF) 23 $780 \mathrm{RU} / \mathrm{mL}$ (N: 10-96). A diagnosis of FGF 23-dependent adult onset hypophosphatemic osteomalacia was made. His positron emission tomography (PET) - GA 68 DOTA scintigraphy displayed a lesion with an increased tracer uptake in the right distal femur (figure 1A, B). He underwent complete excision biopsy of the above lesion which was characteristic of phosphaturic mesenchymal tumour (figure 2) suggesting a diagnosis of oncogenic osteomalacia. On follow-up at 2 months, he made remarkable recovery and his serum phosphorus and FGF23 levels were within normal limits.

Oncogenic osteomalacia, is an uncommon paraneoplastic syndrome characterised by severe hypophosphataemia secondary to mesenchymal tumours secreting phosphotonins like FGF23. Usually they are located in the head and neck region. ${ }^{1}$ The GA DOTATATE PET/CT study is the investigation of the choice for the localisation. Once these tumours are completely excised, most of the patients improve significantly and remain symptom free. ${ }^{2}$

\section{Learning points}

Oncogenic osteomalacia (otherwise known as tumour-induced osteomalacia) is a rare cause of hypophosphataemic osteomalacia secondary to mesenchymal tumours.

- Most of these tumours are usually located in the head and neck region which secrete phosphotonins (eg, phosphaturic factors) like fibroblast growth factor 23 causing renal phosphate loss and osteomalacia.

- The GA DOTATATE PET/CT study is the investigation of the choice for the localisation.

Contributors SS and NK wrote the manuscript and were involved in clinical care of the patient. VMC and TVP reviewed the 
manuscript and were involved in clinical care of the patient. SS, NK, VMC and TVP approved the manuscript before submission.

\section{Competing interests None.}

Patient consent Obtained.

Provenance and peer review Not commissioned; externally peer reviewed.

\section{REFERENCES}

1 Chong WH, Molinolo AA, Chen CC, et al. Tumor-induced osteomalacia. Endocr Relat Cancer 2011;18:R53-77.

2 Agrawal K, Bhadada S, Mittal BR, et al. A Comparison of 18F-FDG and 68Ga DOTATATE PET/CT in Localization of Tumor causing Oncogenic Osteomalacia. Clin Nucl Med 2015;40:e6-e10.

Copyright 2015 BMJ Publishing Group. All rights reserved. For permission to reuse any of this content visit

http://group.bmj.com/group/rights-licensing/permissions.

BMJ Case Report Fellows may re-use this article for personal use and teaching without any further permission.

Become a Fellow of BMJ Case Reports today and you can:

- Submit as many cases as you like

- Enjoy fast sympathetic peer review and rapid publication of accepted articles

- Access all the published articles

- Re-use any of the published material for personal use and teaching without further permission

For information on Institutional Fellowships contact consortiasales@bmjgroup.com

Visit casereports.bmj.com for more articles like this and to become a Fellow 